\title{
ПЕРСПЕКТИВНЫЕ НАПРАВЛЕНИЯ ИСПОЛЬЗОВАНИЯ БИОЛОГИЧЕСКИХ И БИОРАЦИОНАЛЬНЫХ ГЕРБИЦИДОВ В РАСТЕНИЕВОДСТВЕ РОССИИ
}

\author{
(обзор)
}

\author{
А.С. ГОЛУБЕВ ${ }^{凶}$, А.О. БЕРЕСТЕЦКИЙ
}

Появление резистентных к химическим гербицидам популяций сорных растений приводит к повсеместному снижению эффективности использования таких препаратов. Несмотря на то, что в Соединенных Штатах Америки, Канаде, Китае и Южной Африке на рынке средств борьбы с сорной растительностью внедряются биологические и биорациональные гербициды (БГБ), в Российской Федерации к настоящему моменту не зарегистрировано ни одного подобного препарата. В то же время развитие исследований по разработке экологически безопасных средств борьбы с сорными растениями позволяет рассчитывать на изменение существующей ситуации (А.О. Берестецкий, 2017; М. Triolet с соавт., 2020). Цель настоящего обзора - анализ современного ассортимента химических гербицидов, разрешенных для применения в России, для выявления рыночных ниш, которые могут занять биологические и биорациональные гербициды в ближайшем будущем. Для оценки перспектив использования БГБ в первую очередь учитывали спектр их действия, обусловленный видовой специфичностью фитопатогенов, который значительно уже спектра гербицидов химического синтеза (А. Berestetskiy с соавт., 2018; A. Berestetskiy, 2021). В основу анализа был положен перечень особо опасных для продукции растительного происхождения вредных организмов, подготовленный Всероссийским НИИ защиты растений (2013), в котором указаны следующие виды сорных растений: осот полевой (Sonchus arvensis L.), бодяк щетинистый (Cirsium setosum (Willd.) Bess.), вьюнок полевой (Convolvulus arvensis L.), пырей ползучий (Elytrigia repens (L.) Nevski) и овсюг обыкновенный (Avena fatua L.). Перечень был дополнен двумя карантинными сорняками, ограниченно распространенными на территории Российской Федерации, но проблемными для ряда регионов, - амброзией полыннолистной (Ambrosia artemisiifolia L.) и горчаком ползучим (Acroptilon repens DC.). Указанные виды сорных растений обладают неодинаковой степенью вредоносности на разных культурах (А.М. Шпанев, 2011). В анализе были задействованы наиболее значимые с точки зрения структуры посевных площадей Российской Федерации сельскохозяйственные культуры. Наиболее перспективно применение БГБ в садах и виноградниках, где, в связи с исключением препаратов на основе глифосата, разрешено использовать лишь глюфосинат аммония (А.С. Голубев с соавт., 2018; А.С. Голубев с соавт., 2019). Кроме того, БГБ, применяемые совместно с этим гербицидом, позволили бы увеличить эффективность обработок и продолжительность защитного эффекта. Риски использования БГБ в садах и виноградниках не выглядят значимыми из-за относительной замкнутости этих агроэкосистем. Кормовые культуры и овощи закрытого грунта не имеют существенного потенциала в качестве ниш для применения БГБ: кормовые культуры - из-за низкой экономической отдачи, а овощи закрытого грунта - ввиду особенностей технологии их выращивания. Перспективным выглядит использование БГБ на полях, предназначенных под посев сельскохозяйственных культур, в осенний период и на паровых полях. В условиях севооборотов БГБ могут использоваться против многолетних корнеотпрысковых сорняков и горчака ползучего в период вегетации сои, подсолнечника и картофеля. На двух последних культурах БГБ могут применяться против амброзии полыннолистной. Занять нишу, связанную с уничтожением злаковых сорных растений (таких как пырей ползучий или овсюг), в условиях сложившегося ассортимента химических гербицидов, будет возможно только для подавления резистентных популяций сорняков.

Ключевые слова: биогербициды, зерновые, кукуруза, соя, подсолнечник, картофель, сады, Sonchus arvensis, Cirsium setosum, Convolvulus arvensis, Elytrigia repens, Avena fatua, Ambrosia artemisiifolia, Acroptilon repens.

Сорные растения представляют собой традиционную проблему при выращивании сельскохозяйственных, лекарственных и декоративных культур. К основным мероприятиям по борьбе с ними относятся применение химических гербицидов и, в меньшей степени, обработка почвы. Вследствие снижения эффективности химической защиты из-за появления устойчивых к гербицидам сорняков, с одной стороны, и за счет увеличения доли потребления органических продуктов питания - с другой, возникает необходимость сокращения использования химических веществ в сельскохозяй- 
ственном производстве. При этом для борьбы с сорными растениями определенные надежды возлагаются на биологические и биорациональные гербициды $(1,2)$.

Известно много примеров широкого и коммерчески успешного использования энтомофагов, микробиологических препаратов, природных соединений для борьбы с возбудителями заболеваний и фитофагами. Как показывает практика, эффективность биологических и биорациональных пестицидов, как правило, существенно ниже, чем химических $(3,4)$. В связи с этим они имеют ограниченное применение: в условиях закрытого грунта, в органическом земледелии, в общественных местах, где использование химического метода запрещено.

Цель настоящего обзора - анализ современного ассортимента химических гербицидов, разрешенных для применения в России, для выявления рыночных ниш, которые могут занять биологические и биорациональные гербициды в ближайшем будущем.

Биогербициды - это препараты для борьбы с сорняками, состоящие из живых микроорганизмов и вспомогательных компонентов (поверхностно-активных веществ, адъювантов, консервантов, водоудерживающих добавок, инертных наполнителей). Поскольку фитопатогенные грибы наиболее часто рассматриваются в качестве активных компонентов биогербицидов (БГБ), препараты на их основе выделяют в отдельную группу и называют микогербицидами (МГБ). Растительные или микробные экстракты с фитотоксическими свойствами, очищенные или полуочищенные природные фитотоксины относят к биорациональным химическим гербицидам (БХГ) (1).

Использование БГБ направлено на то, чтобы вызвать локальные эпифитотии в популяциях нежелательных растений и, как следствие, снизить их конкурентоспособность. БГБ рассчитаны на регулярное применение, однако их действие может быть пролонгированным на несколько сезонов. БГБ - селективные микробиологические препараты, которые подавляют один или несколько видов сорняков. В состав некоторых БГБ входят слабоспециализированные фитопатогены, встречающиеся как на целевых сорняках, так и на культурных растениях. Такие патогены могут быть использованы в особых ситуациях, когда восприимчивые культуры не высеваются или не включаются в севооборот, где планируется биоконтроль сорняков (5-7).

Гербицидные препараты на основе природных фитотоксинов (биорациональные гербициды) имеют определенные преимущества перед БГБ: понятные механизмы действия и контроль качества, существенно меньшая зависимость эффективности от внешних факторов. Фитотоксические соединения - преимущественно вторичные метаболиты растений (эффект аллелопатии) и микроорганизмов (факторы патогенности или колонизации растений), в небольших концентрациях убивающие клетки растений. Кроме того, фитотоксическими свойствами обладают некоторые первичные метаболиты: ряд аминокислот, некоторые органические и жирные кислоты $(8,9)$.

Существующие биорациональные средства защиты растений, включая БХГ, можно условно разделить на четыре группы: микробные препараты токсинного действия; грубые экстракты растительного или микробного происхождения; индивидуальные природные соединения (или их смеси) различной степени очистки; синтетические аналоги природных соединений (10). Последние, строго говоря, не относятся к природным, поэтому в настоящей статье химические гербициды на их основе мы рассматривать не будем. 
K первой группе относятся такие препараты, как Bioprotec Herbicide $^{\text {тм }}$ («AEF Global, Inc.», Канада), который состоит из лактобактерий, образующих фитотоксичные молочную и лимонную кислоты, для подавления роста клевера на газонах (11). Для борьбы с паразитическим сорняком стригой Striga hermonthica (Delile) Benth. в США разработан биогербицид на основе Fusarium oxysporum, суперпродуцента тирозина - аминокислоты, обладающей способностью к ингибированию развития стриги (12). МГБ на основе гриба Phoma macrostoma («Evologic Technologies GmbH», Австрия) действует за счет фитотоксинов из группы макрооксазолов $(13,14)$.

В следующую группу БХГ входят эфирные масла, растительные экстракты, сидераты, отходы пищевого производства (15). Так, в США в качестве БХГ используют кукурузный глютен, при разложении которого образуются фитотоксичные пептиды (16). Измельченная зеленая масса горчицы и соевая мука (норма расхода соответственно около 1 и 4 т/га) были эффективны для подавления сорняков в посевах шпината Spinacia oleracea L. и брокколи Brassica oleracea L. var. italica в условиях органического земледелия (17).

Высокую гербицидную активность показал экстракт из бобового растения канавалия Canavalia ensiformis (L.) DC. для подавления плюща Ipomoea grandifolia (Dammer) О’Donell и коммелинии Commelina benghalensis L. в посевах сои (18). Эфирные масла примерно 20 видов растений, используемые для борьбы с различными видами сорняков, рассмотрены в обзоре R. Raveau с соавт. (19). Интересным представляется применение эфирных масел сорных видов амброзии, которые обладают фитотоксическими свойствами (20). Фенольные вещества из Ludwigia hyssopifolia (G. Don) Exell обеспечивали значительное подавление роста побегов и накопления биомассы Amaranthus spinosus L., Dactyloctenium aegyptium L., Cyperus iria L. (21).

Известны несколько коммерческих и экспериментальных БХГ из третьей группы биорациональных средств защиты растений. Для борьбы с сорными растениями на приусадебных участках в США применяют уксусную кислоту (16). Эффективной может быть гербицидная смесь на основе уксусной и лимонной кислот (22). Из биомассы ипомеи Ipomoea tricolor Cav., которую мексиканские фермеры используют как покровную культуру на сахарном тростнике для подавления сорной растительности, выделен фитотоксичный гликозид триколорин А. Этот фитотоксин в концентрации 60 мкМ действует как неселективный ингибитор прорастания семян и роста побегов растений и может рассматриваться как альтернатива глифосату (23). Компания «Marrone BioInnovations» (США) разработала препарат Opportune ${ }^{\circledR}$, действующим веществом которого служит бактериальный фитотоксин такстомин А. Компания «Belchim Crop Protection» (Бельгия) предлагает БХГ Katoun ${ }^{\circledR}$ Gold на основе пеларгоновой кислоты для использования в органическом земледелии (11). Тенуазоновая кислота, образуемая некоторыми грибами из рода Alternaria, запатентована китайскими учеными и изучается как природный гербицид с оригинальным механизмом действия. Разработан ее химический синтез и показана возможность практического применения в полевых условиях (24).

Как показывает анализ литературы, в мире ведется активный поиск новых гербицидных соединений природного происхождения (25). Сотрудники компании «Dow AgroSciences LLC» (США) выявили целый ряд микробных фитотоксинов, перспективных для создания новых БХГ: макроцидин (26), циннацидин (27), альбуцидин (28), мевалоцидин (29). Кордицепин (метаболит гриба Cordyceps militaris (L.) Fr.) в концентрации 0,04 мг/мл 
подавлял рост корней редиса в несколько раз сильнее, чем бензойная кислота и глифосат (30).

Из листьев Plumbago auriculata (Lam.) Spach выделено природное соединение плюмбагин (5-гидрокси-2-метил-1,4-нафтохинон), которое было эффективно в полевых условиях против ряда однодольных и двудольных сорных растений (31). Аилантон из Ailanthus altissima (Mill.) Swingle перспективен для разработки нового природного гербицида (32). Асптерровая кислота (один из вторичных метаболитов гриба Aspergillus terreus Thom) - высокоактивный ингибитор дегидратазы дигидроксикислот и эффективный послевсходовый гербицид (33).

Чтобы повысить эффективность борьбы с сорными растениями, можно совместно применять различные химические гербициды, БХГ и БГБ с целью усиления их действия (34). Достаточно давно для органического земледелия и на газонах используются смеси природных продуктов, например уксусной кислоты, экстракта лимона и клеверного масла (35). Разработана композиция, повышающая эффективность глифосата (0,8-1,2 л/га), которая включает смесь L-2-амино-2-метил-меркаптомасляной кислоты, $\mathrm{L}-\alpha$-диаминокапроновой кислоты и L- $\beta$-фенил- $\alpha$-аминопропионовой кислоты (примерно 10 г/га при соотношении компонентов 2:1:1) и аммиачную селитру (2 кг/га). Повышение эффективности глифосата обеспечивается за счет более активного поглощения гербицида сорняками, что позволяет снизить норму его расхода. Микрополевые и полевые испытания показали возможность снижения норм внесения глифосата примерно в 2 раза при совместном применении со смесью янтарной и яблочной кислот в концентрации 10-11 М (36). Смесь эфирного масла мануки Leptospermum scoparium J.R. Forst. \& G. Forst. и пеларгоновой кислоты была эффективна против трех видов сорных растений (Lolium rigidum Gaud., Avena sterilis L. и Galium aparine L.) (37).

В Российской Федерации нет зарегистрированных БГБ и БХГ, а исследований в этом направлении проводится немного. В частности, запатентованы продуценты гербицидных соединений (феосферида А, стагонолида А, гербарумина I) - штаммы грибов Paraphoma sp. и Stagonospora cirsii. Разработаны способы их применения, однако отсутствуют четкие представления о перспективах использования, слабо изучены токсикология и способы пилотного получения для проведения полевых испытаний (38).

Эффективность БГБ и БХГ ниже, чем у химических гербицидов, площадь обработок не может быть большой, а срок хранения таких препаратов ограничен. Однако они могут быть использованы в органическом земледелии или в качестве компонента комплексной борьбы с особо вредоносными сорняками.

Следующий за созданием препарата этап его регистрации требует значительных финансовых затрат. Обычно подобные траты доступны крупным химическим компаниям, отделы маркетинга которых рассчитывают приблизительную окупаемость затрат по выведению биогербицида на рынок. При этом даже серьезные вложения в регистрацию препарата не всегда окупаются его высокой активностью в полевых условиях (4).

Наиболее важным этапом при планировании стратегии доведения научных разработок биологических и биорациональных гербицидов до конечного потребителя должно стать, на наш взгляд, четкое выделение рыночных ниш для их экономически оправданного применения, а также оценка перспектив на рынке с учетом сложившегося ассортимента химических гербицидов для защиты основных сельскохозяйственных культур. Следует отметить, что такой подход особенно значим в России, где пока не 
зарегистрировано ни одного подобного препарата.

Для оценки рыночных перспектив БГБ важно учитывать спектр их действия, обусловленный видовой специфичностью фитопатогенов. Необходим перечень видов сорных растений, использование биопрепаратов против которых может быть целесообразным. Также следует отметить, что БХГ на основе органических кислот, жиров и масел, полученных из растений, менее эффективны, чем химические средства, и требуют значительных объемов внесения, что затрудняет использование БХГ в промышленном растениеводстве (39).

В 2013 году Всероссийским НИИ защиты растений были подготовлены перечни особо опасных для продукции растительного происхождения вредных организмов, в которых указаны следующие виды сорных растений: осот полевой (Sonchus arvensis L.), бодяк щетинистый (Cirsium setosum (Willd.) Bess.), вьюнок полевой (Convolvulus arvensis L.), пырей ползучий (Elytrigia repens (L.) Nevski) и овсюг обыкновенный (Avena fatua L.) (40). Этот перечень, на наш взгляд, можно взять за основу и дополнить его двумя карантинными сорняками, ограниченно распространенными на территории Российской Федерации, но проблемными для ряда регионов, - амброзией полыннолистной (Ambrosia artemisiifolia L.) и горчаком ползучим (Acroptilon repens DC.) (41). Указанные виды сорных растений обладают неодинаковой степенью вредоносности на разных культурах.

Составить перечень наиболее значимых сельскохозяйственных культур позволяет анализ структуры посевных площадей Российской Федерации. В 2019 году зерновые и зернобобовые культуры занимали 58,4 \% общего количества посевных площадей, технические - 19,9 \%, кормовые $19,3 \%$ (42). Можно предположить, что последняя группа не имеет значительного потенциала в качестве ниши для применения микогербицидов изза низкой экономической отдачи. Овощи закрытого грунта ввиду особенностей технологии их выращивания также не выглядят перспективно.

Зерновые культуры рассмотрим в совокупности, поскольку большинство гербицидов разрешено для применения одновременно на пшенице (озимой и яровой), ячмене (яровом и озимом) и овсе. В качестве отдельных культур возьмем наиболее распространенные: сою из группы зернобобовых, доля которых составляет 2,7 \% от общего количества всех посевных площадей, кукурузу $(3,2 \%)$, подсолнечник $(10,7 \%)$ и картофель $(1,6 \%)(42)$. Чтобы систематизировать подход к анализу, далее мы описали вид сорного растения, степень его угрозы для культуры, ассортимент гербицидов, способных эффективно контролировать численность объекта в посевах культуры, и возможные альтернативные решения.

Осот полевой, бодяк щетинистый и вьюнок полевой относятся к группе многолетних корнеотпрысковых сорняков. Присутствие бодяка и осота среди доминирующих видов характерно для большинства регионов России; вьюнок полевой чаще встречается в средних и южных регионах (43). Согласно исследованиям А.М. Шпанева (2011-2013 годы), эти многолетние сорные растения по своей вредоносности значительно превосходят однолетние сорняки (44-46).

Обычно с ними борются посредством внесения общеистребительных гербицидов на основе глифосата: Раундап Макс, ВР (450 г/л глифосата/изопропиламинная соль), Спрут Экстра, ВР (540 г/л глифосата /калиевая соль), Килео, ВРК (240 г/л глифосата/изопроламинная соль + 160 г/л 2,4-Д/3алкиламинопропилдиметиламинная соль) и др. Однако использование этих препаратов, как правило, возможно лишь на паровых полях и на полях, предназначенных под посев или посадку различных сельскохозяйственных 
культур в конце лета или осенью в послеуборочный период (47). На отдельных культурах (подсолнечник, соя) препараты можно вносить за 2-5 сут до посева, на кукурузе - за 2 нед до посева, на картофеле - за 2-5 сут до появления всходов культуры.

Несмотря на высокую эффективность общеистребительных гербицидов в борьбе с многолетними корнеотпрысковыми сорняками, такие обработки становятся превентивной мерой, что не вполне соответствует современным представлениям об экологическом пути развития защиты растений. К тому же, ввиду возможных ограничений или даже запрета использования глифосата в нашей стране (48), имеет смысл обращать основное внимание на препараты для борьбы с многолетними корнеотпрысковыми сорняками в период вегетации.

Значительное количество таких препаратов есть среди гербицидов для защиты зерновых культур. К узкоспециализированным гербицидам против осота и бодяка относятся препараты на основе клопиралида, такие как Лонтрел-300, ВР (300 г/л), Хакер, ВРГ (750 г/кг), Лонтрел гранд, ВДГ (750 г/кг); против вьюнка полевого - на основе флуроксипира: Деметра, КЭ (350 г/л), Старане Премиум 330, КЭ (333 г/л). Разработаны препараты более широкого спектра действия на основе проверенных и хорошо зарекомендовавших себя в производстве действующих веществ, таких как эфиры 2,4-Д кислоты - Эстерон 600, КЭ (600 г/л), Дротик, ККР (400 г/л), Эстет, КЭ (600 г/л); сульфонилмочевины - Ларен Про, ВДГ (600 г/кг метсульфурон-метила), Трибун, СТС (750 г/кг трибенурон-метила) и др. Помимо этого, существует значительное число комбинированных препаратов, которые обладают высокой активностью против многолетних корнеотпрысковых сорняков: Прима, СЭ (300 г/л 2,4-Д/сложный 2-этилгексиловый эфир/ + 6,25 г/л флорасулама), Бомба, ВДГ (563 г/кг трибенурон-метила +187 г/кг флорасулама), Унико, ККР (100 г/л флуроксипира + 2,5 г/л флорасулама) и др. (49).

На посевах кукурузы зачастую используются те же препараты, что и на зерновых культурах (50). Из специфичных для кукурузы гербицидов комплексного действия можно привести в пример гербицид Модерн, КЭ (412 г/л 2,4-Д/сложный 2-этилгексиловый эфир/ + 80 г/л никосульфурона +8 г/л флорасулама).

Число гербицидов для борьбы с многолетними двудольными сорными растениями на посевах сои, подсолнечника и посадках картофеля существенно меньше. Если рассматривать сою, то в отношении указанных вредных объектов некоторую активность проявляют гербициды Хармони Классик, ВДГ (187,5 г/кг тифенсульфурон-метила + 187,5 г/кг хлоримуронэтила) и Фабиан, ВДГ (450 г/кг имазетапира + 150 г/кг хлоримурон-этила). Использовать химические препараты для подавления видов бодяка и осота на посевах подсолнечника во время вегетации культуры можно только на специальных гибридах, устойчивых к сульфонилмочевинам, например к трибенурон-метилу (51). Для этих целей применяют Экспресс, ВДГ (750 г/кг трибенурон-метила), Санфло, ВДГ (750 г/кг), Прометей, ВДГ (750 г/кг). В период вегетации картофеля некоторая активность против многолетних корнеотпрысковых сорных растений наблюдается при использовании препаратов на основе римсульфурона - Титус, СТС (250 г/кг), Кассиус, ВРП (250 г/кг), Эскудо, ВДГ (500 г/кг), хотя решить проблему, ограничиваясь использованием лишь этих препаратов, затруднительно (52).

На наш взгляд, именно ниша борьбы с многолетними двудольными сорными растениями выглядит наиболее привлекательной для использования биогербицидов. С одной стороны, это обусловлено существующим 
ассортиментом химических гербицидов (и возможным исключением глифосата из числа разрешенных для применения препаратов), с другой - самим количеством патогенов многолетних корнеотпрысковых сорняков. Так, только для борьбы с бодяком полевым рассматривались Phoma destructiva, Phoma hedericola, Phoma exigua, Puccinia punctiformis, Mycelia sterilia, Phomopsis cirsii, Sclerotinia sclerotiorum, Alternaria cirsinoxia, Stagonospora cirsii, Septoria cirsii, Phyllosticta cirsii (53-55).

Горчак ползучий, по состоянию на 1 января 2019 года, встречался в 19 субъектах Российской Федерации, а площадь установленных карантинных фитосанитарных зон превышала 1885590 га (56).

Как правило, борьба с горчаком наиболее эффективна на паровых полях и полях, предназначенных под посев зерновых культур. Используют следующие препараты: Генсек, ВРГ (88,5 г/л дикамбы + 88,5 г/л пиклорама + 177 г/л клопиралида), Горгон, ВРК (350 г/л МЦПА кислоты + 150 г/л пиклорама) (57). В период вегетации культуры можно применять Октимет, КЭ (500 г/л 2,4-Д кислоты + 5,5 г/л метсульфурон-метила) или Ланцелот 450, ВДГ (300 г/кг аминопиралида + 150 г/кг флорасулама).

Ассортимент гербицидов этого направления небольшой, а поскольку препараты для борьбы с горчаком обычно имеют строгие ограничения по севообороту (58), потенциально привлекательна разработка альтернативных, в том числе биологических, средств борьбы. Еще большую актуальность этому направлению придает то, что гербицидов, разрешенных для применения по вегетирующим растениям кукурузы, сои, подсолнечника и картофеля для контроля горчака, не существует.

В конце XX века были предприняты попытки использования в качестве биогребицидов для борьбы с горчаком ползучим нематод из рода Subanguina picridis Kirj. \& Ivan (59). В начале XXI века для этой цели предложили использовать аллелопатический эффект эфирных масел эвкалипта, кипариса Лоусона, розмарина и белого кедра (60).

Амброзия полыннолистная, по данным на 1 января 2019 года, встречалась в 31 субъекте Российской Федерации, площадь установленных карантинных зон превышала 7356593 га (56). Следует отметить, что амброзия полыннолистная не только ухудшает условия произрастания культурных растений, снижая их урожайность, но и вызывает аллергические реакции (61).

Как и в случае с многолетними двудольными сорняками, для борьбы с этим видом на посевах зерновых культур можно применять гербициды на основе клопиралида, например Агрон, ВР (300 г/л), Агрон Гранд, ВДГ (750 г/кг), а также использовать препараты более широкого спектра действия, в том числе комбинированные - Примадонна, СЭ (200 г/л 2,4-Д кислоты + 3,7 г/л флорасулама), Балерина, СЭ (410 г/л 2,4-Д кислоты + 7,4 г/л флорасулама) (62). Эти комбинированные гербициды могут применяться и на посевах кукурузы. Кроме того, на посевах кукурузы используют специфичные для этой культуры гербициды МайсТер, ВДГ (300 г/кг форамсульфурона +10 г/кг йодосульфурон-метил-натрия +300 г/кг антидота изоксадифен-этила) и МайсТер Пауэр, МД (31,5 г/л форамсульфурона +1 г/л йодосульфурон-метил-натрия + 10 г/л тиенкарбазон-метила + 15 г/л антидота ципросульфамида) (63).

Соя относится к бобовым растениям и проявляет природную устойчивость к гербицидам группы имидазолинонов, которые позволяют эффективно уничтожать растения амброзии полыннолистной. В качестве примеров таких препаратов можно привести Пульсар, ВР (40 г/л имазамокса) и Пивот, ВК (100 г/л имазетапира). Кроме того, в борьбе с этим вредным 
объектом на сое успешно используют гербициды на основе бентазона Базагран, ВР (480 г/л), Корсар, ВРК (480 г/л), Бенито, ККР (300 г/л), а также комбинированные препараты, например Корум, ВРК (480 г/л бентазона $+22,4$ г/л имазамокса) (64).

При возделывании гибридов подсолнечника, устойчивых к имидазолинонам, внесение гербицидов этой группы позволяет эффективно уничтожать растения амброзии полыннолистной. В качестве примеров таких препаратов можно привести Евро-Лайтнинг, ВРК (33 г/л имазамокса + 15 г/л имазапира), Пульсар, ВР (40 г/л имазамокса), Тапир Гибрид, МК (50 г/л имазетапира + 20 г/л имазапира) (65).

Поскольку клопиралид, бентазон и имидазолиноны не рекомендованы для применения на посадках картофеля, высокоэффективных средств борьбы с амброзией полыннолистной во время вегетации этой культуры не существует.

Следует отметить, что из-за значительного запаса семян амброзии в почве в посевах сельскохозяйственных культур может наблюдаться вторая, а иногда и третья волна всходов этого сорного растения. В этот период борьба с сорняком агротехническим и химическим методами затруднена в силу особенностей биологии культурных растений. В результате растения амброзии проходят весь биологический цикл развития, включая созревание семян, что приводит к еще большему их распространению (66). Следовательно, невзирая на широкий ассортимент гербицидов для борьбы с этим объектом, биопрепараты могут быть включены в систему защитных мероприятий против амброзии полыннолистной в дополнение к химическим средствам.

Перспективным направлением представляется использование эфирных масел Nepeta rtanjensis Dikli и Milojevi, а также N. cataria L. (67). Применение биофумигации, основанной на аллопатических механизмах взаимоотношений между горчицей Brassica juncea (L.) Czern. и этим сорняком, позволяет снижать количество проростков последнего (68).

Пырей ползучий - один из наиболее злостных сорняков, встречающийся повсеместно. В засушливых условиях южных степей, полупустынь и пустынь он теряет свое значение сорного растения (69). Как правило, не имеет широкого распространения в посевах зерновых культур, а его появление в них свидетельствует о низкой культуре земледелия.

В посевах кукурузы пырей ползучий в некоторых регионах (например, в Центральном районе Нечерноземной зоны) встречается довольно часто (70). Борьбу с сорняком осуществляют с помощью гербицидов на основе римсульфурона - Титус, СТС (250 г/кг), Кассиус, ВРП (250 г/кг); никосульфурона - Ниссин, КС (40 г/л), Иканос, МД (40 г/л), Инновейт, КС (240 г/л), ДУБЛОН, СК (40 г/л) или комбинированных препаратов - Кордус, ВДГ (500 г/кг никосульфурона + 250 г/кг римсульфурона), Элюмис, МД (75 г/л мезотриона + 30 г/л никосульфурона) (71).

Для защиты посевов сои, подсолнечника и посадок картофеля можно использовать препараты на основе флуазифоп-П-бутила - Фюзилад Форте, КЭ (150 г/л), Фюзилад Супер, КЭ (125 г/л); квизалофоп-П-тефурила - Багира, КЭ (40 г/л), Пантера, КЭ (40 г/л), Хилер, МКЭ (40 г/л); клетодима - Селект, КЭ (120 г/л), Центурион, КЭ (240 г/л). При этом на картофеле, кроме перечисленных, применяют гербициды на основе римсульфурона (72).

Согласно имеющимся данным, большинство биологических средств подавления пырея ползучего пока слишком дороги и связаны с высокими трудозатратами (73), поэтому конкретных разработок в этом направлении немного. 
Овсюг обыкновенный нуждается в теплом климате и сухих почвах. Его основной ареал и зоны вредоносности расположены на юго-востоке европейской части России и Южном Урале, где овсюг доминируют в посевах зерновых культур (43).

Ассортимент гербицидов против овсюга, рекомендованных для применения на этих культурах, чрезвычайно широк. Он включает в себя препараты на основе феноксапроп-П-этила - Пума Супер 7.5, ЭМВ (69 г/л + 75 г/л антидота мефенпир-диэтила), Оцелот, КЭ (100 г/л + 27 г/л антидота клоквинтосет-мексила); клодинафоп-пропаргила - Топик, КЭ $(80$ г/л +20 г/л антидота клоквинтосет-мексила); пиноксадена - Аксиал 50, КЭ (50 г/л + 12,5 г/л антидота клоквинтосет-мексила); флукарбазона натрия - Эверест, ВДГ (700 г/кг) и др. При смешанном типе засоренности используются препараты для комплексного подавления двудольных сорных растений и однолетних злаковых сорняков Алистер Гранд, МД (6 г/л мезосульфурон-метила + 4,5 г/л йодосульфурон-метил-натрия + 180 г/л дифлюфеникана + 27 г/л мефенпир-диэтила), Оцелот Кросс, КЭ (290 г/л МЦПА кислоты/2 этилгексиловый эфир/ + 49 г/л феноксапроп-П-этила + 15 г/л клоквинтосет-мексила) (74).

Для защиты посевов кукурузы, сои, подсолнечника и посадок картофеля от однолетних злаковых сорняков, к числу которых относят овсюг, используют те же препараты, что и для борьбы с пыреем. Дополнительно к перечисленным средствам на посадках картофеля можно применять гербициды на основе метрибузина - Зенкор Ультра, КС (600 г/л), Лазурит, СП (700 г/кг), Сойл, ВДГ (700 г/кг) (75).

Следует отметить, что в будущем актуальной проблемой может стать появление резистентных популяций овсюга обыкновенного. Сообщения о резистентности овсюга к феноксапроп-П-этилу были получены из Алтайского края (76). Разработка биогербицидов для борьбы с резистентными формами может быть перспективной, несмотря на широкий арсенал химических гербицидов.

БГБ и БХГ против овсюга нет, хотя за рубежом достаточно давно ведутся исследования по выявлению и применению его различных патогенов, а также поиски природных соединений, ингибирующих его рост. В частности, изучена микобиота семян овсюга с целью снижения их жизнеспособности $(77,78)$, в полевых условиях испытан ржавчинный гриб (79), изучены условия заражения Drechslera avenae и круг восприимчивых к нему растений $(80,81)$. В Австралии, где овсюг оказался заносным видом, для борьбы с ним предложен $D$. avenae, но в России этот гриб служит возбудителем болезни овса и поэтому вряд ли может применяться там, где выращивают эту культуру. В то же время из культуры D. avenae выделен неселективный фитотоксин пиренофорол А, который обладает гербицидным потенциалом для борьбы с овсюгом и другими сорняками (82-84). Также для борьбы с овсюгом предложено использовать эфирные масла эвкалипта $(85,86)$, биоактивные сесквитерпены из амброзии (87) и даже экстракт папайи (Carica papaya L.) (88).

Из-за особой актуальности (опасности для человека и быстрого распространения) мы не можем обойти вниманием борщевик Сосновского (Heracleum sosnowskyi Manden.), который имеет ограниченное распространение на сельскохозяйственных землях из-за комплекса проводимых на них агротехнических мероприятий. Как правило, нахождение экземпляров борщевика Сосновского на пашне свидетельствует об очень низкой культуре земледелия. Основными местами произрастания этого вида становятся земли несельскохозяйственного назначения, пастбища и сенокосные 
угодья, канавы и обочины дорог, а также участки, занятые лесной растительностью.

Ассортимент гербицидов, разрешенных для применения против борщевика Сосновского на землях несельскохозяйственного назначения, включает препараты на основе глифосата - Торнадо, ВР (360 г/л), Тотал, ВР (360 г/л); сульфометурон-метила - Анкор-85, ВДГ (750 г/кг); метсульфуронметила - Зингер, СП (600 г/кг); имазапира - Шквал, ВК (250 г/л), Арбонал, BK (250 г/л). Часть препаратов представляет комбинации из указанных действующих веществ - АтронПро, ВДГ (250 г/кг имазапира +75 г/кг сульфометурон-метила), Горгон, ВРК (350 г/л МЦПА кислоты + 150 г/л пиклорама), Гранж, ВДГ (525 г/кг глифосата (калиевая соль) + 105 г/кг сульфометурон-метила + 20 г/кг хлорсульфурона) и Генсек, ВРГ (88,5 г/л дикамбы $+88,5$ г/л пиклорама +177 г/л клопиралида). На сенокосных угодьях и пастбищах для борьбы с борщевиком Сосновского разрешено использование гербицидов на основе дикамбы, например Банвела, ВР (480 г/л), Дианата, ВР (480 г/л).

С одной стороны, широкий ассортимент представленных на рынке химических гербицидов для борьбы с борщевиком Сосновского не открывает широких возможностей для внедрения в него биогербицидов. С другой стороны, потенциально интересной нишей использования биопрепаратов может быть их совместное применение с селективными гербицидами на основе сульфонилмочевин или дикамбы. Дело в том, что одно из основных условий достижения долгосрочного эффекта в уничтожении борщевика Сосновского - недопущение повторного засорения очищенных от сорняка участков. Для этих целей используются либо «замещающие посадки» в виде газонных трав, либо полное уничтожение двудольных сорных растений для образования «дернины» посредством селективных в отношении злаков гербицидов, которые потенциально могут быть дополнены биопрепаратами. Отметим, что исследования в этом направлении должны включать в себя изучение совместимости сульфонилмочевин и дикамбы с продуцентами биогербицидов.

Анализ ниш, потенциально привлекательных для внедрения биопрепаратов в производство сельскохозяйственной продукции, был бы неполным без упоминания о садах и виноградниках. Для борьбы с сорными растениями здесь разрешены только общеистребительные препараты на основе двух действующих веществ - глифосата (в виде солей) и глюфосината аммония (89). В настоящее время использование препаратов на основе глифосата в нашей стране существенно ограничено и ниша оперативных средств борьбы с сорняками в садах и виноградниках вакантна (48). Занять ее могли бы биогербициды, которые стали бы особенно востребованными в контексте борьбы со всеми указанными в статье проблемными видами сорных растений, а особенно с многолетними видами (известно, что в садах и виноградниках складываются благоприятные условия для роста и развития горчака) (90).

Еще одно преимущество использования биогербицидов в садах и виноградниках - возможность их применения после внесения глифосата. При таких технологиях наблюдается более пролонгированное действие обработки (91). Также возможно совместное использование биогербицидов с химическими препаратами, при котором увеличивается эффективность подавления сорняков (92).

Немаловажное преимущество биогербицидов в садах - возможность оградить нецелевые объекты от отрицательного влияния БГБ в отдаленной 
перспективе. В отличие от химических гербицидов, которые широко используются в производстве более полувека, последствия применения биогербицидов можно спрогнозировать лишь эмпирически. Это вызывает серьезные опасения ученых, поскольку известны факты неудачного внедрения таких препаратов (93-95).

Принимая во внимание возможные отдаленные последствия использования биогербицидов, сфера относительно замкнутой агроэкосистемы сада выглядит наиболее предпочтительно для попытки первой апробации таких препаратов в сельскохозяйственном производстве. Вторым этапом внедрения биогербицидов в производство может стать их включение в системы севооборота на полях, предназначенных под посев сельскохозяйственных культур, в осенний период. В этом случае с момента применения препаратов до посева культур пройдет несколько месяцев. При условии успешного завершения двух первых этапов биогербициды можно использовать на паровых полях. Завершающим этапом станет их применение на посевах и посадках сельскохозяйственных культур.

В заключение приведем список упомянутых в обзоре препаратов: Название препарата

Раундап Макс, ВР
Спрут Экстра, ВР

Спрут Экстр

Колте, ВРК

Хакер, ВРГ

Лонтрел гранд, ВДГ

Деметра, КЭ

Старане Премиум 330, КЭ

Эстерон 600, КЭ

Дротик, ККР

Эстет, КЭ

Ларен Про, ВДГ

Трибун, СТС

Прима, СЭ

Бомба, ВДГ

Унико, ККР

Модерн, КЭ

Классик Форте, ВДГ

Фабиан, ВДГ

Экспресс, ВДГ

Санфло, ВДГ

Прометей, ВДГ

Титус, СТС

Кассиус, ВРП

Эскудо, ВДГ

Генсек, ВРГ

Горгон, ВРК

Октимет, КЭ

Ланцелот 450, ВДГ

Агрон, ВР

Агрон Гранд, ВДГ

Примадонна, СЭ

Балерина, СЭ

МайсТер, ВДГ

МайсТер Пауэр, МД

Пульсар, ВР

Пивот, ВК

Базагран, ВР

Kopcap, BPK

Бенито, ККР

Корум, ВРК

Евро-Лайтнинг, ВРК

Пульсар, ВР

Тапир Гибрид, МK

Титус, СТС

Кассиус, ВРП

Ниссин, КС

Иканос, МД

Инновейт, КС

ДУБЛОН, СК

Кордус, ВДГ
«Monsanto Europe S.A.», Бельгия

«O «Щелал GmbH \& Co KG», Австрия

«Dow AgroSciences Vertriebsgesellschaft m.b.Н», Австрия

АО Фирма «Август», Россия

«Dow AgroSciences Vertriebsgesellschaft m.b.Н», Австрия

АО Фирма «Август», Россия

«Dow AgroSciences Vertriebsgesellschaft m.b.Н», Австрия

«Dow AgroSciences Vertriebsgesellschaft m.b.H», Австрия

АО «Щелково Агрохим», Россия

«Nufarm GmbH \& Co KG», Австрия

ООО «Дюпон Наука и Технологии», Россия

ООО «Агро Эксперт Груп», Россия

«Dow AgroSciences Vertriebsgesellschaft m.b.Н», Австрия

АО Фирма «Август», Россия

АО «Щелково Агрохим», Россия

ООО ГК «ЗемлякоФФ», Россия

ООО «Дюпон Наука и Технологии», Россия

АО Фирма «Август», Россия

ООО «ЭфЭмСи», Россия

АО «Щелково Агрохим», Россия

ООО «Ярило», Россия

ООО «Дюпон Наука и Технологии», Россия

АО «Щелково Агрохим», Россия

АО Фирма «Август», Россия

ООО «Агро-Инновации», Россия; ООО «Агрусхим», Россия

АО Фирма «Август», Россия

ООО «Алсико-Агропром», Россия; ООО «Агроимпэкс», Россия

«Dow AgroSciences Vertriebsgesellschaft m.b.Н», Австрия

ООО «Агро Эксперт Груп», Россия

ООО «Агро Эксперт Груп», Россия

АО «Щелково Агрохим», Россия

АО Фирма «Август», Россия

«Bayer CropScience AG», Германия

«Bayer CropScience AG», Германия

«BASF Agrochemical Products B.V.», Нидерланды

«BASF Agrochemical Products B.V.», Нидерланды

«BASF SE», Германия

АО Фирма «Август», Россия

АО «Щелково Агрохим», Россия

«BASF Agrochemical Products B.V.», Нидерланды

«BASF Agrochemical Products B.V.», Нидерланды

«BASF Agrochemical Products B.V.», Нидерланды

ООО «Агро Эксперт Груп», Россия

ООО «Дюпон Наука и Технологии», Россия

АО «Щелково Агрохим», Россия

«ISK Biosciences Europe N.V.», Бельгия

«Nufarm GmbH \& Co KG», Австрия

«Cheminova A/C», Дания

АО Фирма «Август», Россия

ООО «Дюпон Наука и Технологии», Россия 
Элюмис, МД

Фюзилад Супер, КЭ

Багира, КЭ

Пантера, КЭ

Хилер, МКЭ

Селект, КЭ

Центурион, КЭ

Пума Супер 7.5, ЭМВ

Оцелот, КЭ

Топик, КЭ

Аксиал 50, КЭ

Эверест, ВДГ

Алистер Гранд, МД

Оцелот Кросс, КЭ

Зенкор Ультра, КС

Лазурит, СП

Сойл, ВДГ

Торнадо, ВР

Тотал, ВР

Анкор-85, ВДГ

Зингер, СП

Шквал, ВК

Арбонал, ВК

АтронПро, ВДГ

Горгон, ВРК

Гранж, ВДГ

Генсек, ВРГ

Банвел, ВР

Дианат, ВР
ООО «Сингента», Россия

ООО «Сингента», Россия

«Arysta LifeScience Great Britain Ltd.», Великобритания

«Arysta LifeScience Great Britain Ltd.», Великобритания

АО «Щелково Агрохим», Россия

«Arysta LifeScience S.A.S.», Франция

«Arysta LifeScience S.A.S.», Франция

«Bayer CropScience AG», Германия

ООО «Агро Эксперт Груп», Россия

ООО «Сингента», Россия

ООО «Сингента», Россия

«Arysta LifeScience S.A.S.», Франция

«Bayer CropScience AG», Германия

ООО «Агро Эксперт Груп», Россия

«Bayer CropScience AG», Германия

АО Фирма «Август», Россия

ООО «Агро Эксперт Груп», Россия

АО Фирма «Август», Россия

ООО «Агро Эксперт Груп», Россия

ООО «Гербицид Первый», Россия

АО «Щелково Агрохим», Россия

АО «Щелково Агрохим», Россия

ООО «Новокеми», Россия

ООО «Агрусхим», Россия

АО Фирма «Август», Россия

ЗАО «Юнайтед Агро», Россия; ЗАО «НПФ «Голицыно Агро», Россия

ООО «Агро-Инновации», Россия; ООО «Агрусхим», Россия

ООО «Сингента», Россия

«BASF Corporation», США

Таким образом, биологические и биорациональные гербициды в ближайшем будущем могут занять ниши в ассортименте средств защиты от сорных растений в садах и виноградниках, на полях под посев яровых культур (при проведении защитных мероприятий в осенний период) и на паровых полях. Разработка биогербицидов против многолетних корнеотпрысковых сорняков и горчака ползучего перспективна для борьбы с этими видами в период вегетации сои, подсолнечника и картофеля. На двух последних культурах в период вегетации перспективны защитные мероприятия с применением биопрепаратов против амброзии полыннолистной. Подобные препараты представляют интерес и в качестве дополнительных способов оперативной борьбы с сорняком наряду с химическими гербицидами. Статус карантинных объектов амброзии полыннолистной и горчака ползучего должен способствовать заинтересованности покупателей в новых экологически безопасных средствах борьбы с ними, даже в присутствии большого количества химических препаратов. $\mathrm{K}$ тому же существующие химические препараты против горчака обладают последействием, что ограничивает их применение в условиях производства. Нишу, связанную с уничтожением злаковых сорных растений (таких как пырей ползучий или овсюг), в условиях сложившегося ассортимента химических препаратов будет достаточно сложно занять биогербицидам. Возможным направлением их использования может стать подавление резистентных популяций названных сорняков, появляющихся в результате широкомасштабного использования химических гербицидов

\section{ЛИТЕРАТУРА}

1. Берестецкий А.О. Биорациональные средства защиты растений. Защита и карантин растений, 2017, 8: 9-14.

2. Triolet M., Guillemin J.-P., Andre O., Steinberg C. Fungal-based bioherbicides for weed control: a myth or a reality? Weed Research, 2020, 60(1): 60-77 (doi: 10.1111/wre.12389).

3. Willoughby I.H., Seier M.K., Stokes V.J., Thomas S.E., Varia S. Synthetic herbicides were more effective than a bioherbicide based on Chondrostereum purpureum in reducing resprouting of Rho- 
dodendron ponticum, a host of Phytophthora ramorum in the UK. Forestry: An International Journal of Forest Research, 2015, 88(3): 336-344 (doi: 10.1093/forestry/cpv004).

4. Tekiela D.R. Effect of the bioherbicide Pseudomonas fluorescens D7 on downy brome (Bromus tectorum). Rangeland Ecology \& Management, 2020, 73(6): 753-755 (doi: 10.1016/j.rama.2019.10.007).

5. Soltys D., Krasuska U., Bogatek R., Gniazdowska A. Allelochemicals as bioherbicides - present and perspectives. In: Herbicides. Current research and case studies in use /A.J. Price, J.A. Kelton (eds.). IntechOpen, 2013 (doi: 10.5772/56185).

6. Hershenhorn J., Casella F., Vurro M. Weed biocontrol with fungi: past, present and future. Biocontrol Science and Technology, 2016, 26(10): 1313-1328 (doi: 10.1080/09583157.2016.1209161).

7. Berestetskiy A., Sokornova S. Production and stabilization of mycoherbicides. In: Biological approaches for controlling weeds /R. Radhakrishnan (ed.). IntechOpen, 2018 (doi: 10.5772/intechopen.76936).

8. Morin L. Annual progress in biological control of weeds with plant pathogens. Annual Review of Phytopathology, 2020, 58: 201-223 (doi: 10.1146/annurev-phyto-010820-012823).

9. Berestetskiy A. Development of mycoherbicides. In: Encyclopedia of mycology /Ó. Zaragoza, A. Casadevall (eds.). Elsevier, 2021, 2: 629-640 (doi: 10.1016/B978-0-12-819990-9.00059-7).

10. Sparks T.C., Bryant R.J. Impact of natural products on discovery of, and innovation in, crop protection compounds. Pest Manag. Sci., 2021 (doi: 10.1002/ps.6653).

11. Cordeau S., Triolet M., Wayman S., Steinberg C., Guillemin J. Bioherbicides: dead in the water? A review of the existing products for integrated weed management. Crop Protection, 2016, 87: 4449 (doi: 10.1016/j.cropro.2016.04.016).

12. Nzioki H.S., Oyosi F., Morris C.E., Kaya E., Pilgeram A.L., Baker C.S., Sands D.C. Striga biocontrol on a toothpick: a readily deployable and inexpensive method for smallholder farmers. Frontiers in Plant Science, 2016, 7: 1121 (doi: 10.3389/fpls.2016.01121).

13. Treiber L., Pezolt C., Zeng H., Schrey H., Jungwirth S., Shekhar A., Stadler M., Bilitewski U., Erb-Brinkmann M., Schobert R. Dual agents: fungal macrocidins and synthetic analogues with herbicidal and antibiofilm activities. Antibiotics, 2021, 10(8): 1022 (doi: 10.3390/antibiotics10081022).

14. Korres N.E., Burgos N.R., Travlos I., Vurro M., Gitsopoulos T.K., Varanasi V.K., Duke S.O., Chad Brabham P.K., Rouse C.E., Salas-Perez R. New directions for integrated weed management: modern technologies, tools and knowledge discovery. Advances in Agronomy, 2019, 155: 243-319 (doi: 10.1016/bs.agron.2019.01.006).

15. Bailey K.L., Pitt W., Derby J., Walter S., Taylor W., Falk S. Efficacy of Phoma macrostoma, a bioherbicide for control of dandelion (Taraxacum officinale) following simulated rainfall conditions. The Americas Journal of Plant Science and Biotechnology, 2010, SI 2: 35-42.

16. Dayan F.E., Duke S.O. Natural products for weed management in organic farming in the USA. Outlooks on Pest Management, 2010, 21(4): 156-160 (doi: 10.1564/21aug02).

17. Shrestha A., Rodriguez A., Pasakdee S., Bacuelos G. Comparative efficacy of white mustard (Sinapis alba L.) and soybean (Glycine max L. Merr.) seed meals as bioherbicides in organic broccoli (Brassica oleracea Var. Botrytis) and spinach (Spinacea oleracea) production. Communications in Soil Science and Plant Analysis, 2015, 46(1): 33-46 (doi: 10.1080/00103624.2014.956884).

18. Mendes I.D.S., Rezende M.O.O. Assessment of the allelopathic effect of leaf and seed extracts of Canavalia ensiformis as postemergent bioherbicides: A green alternative for sustainable agriculture. Journal of Environmental Science and Health, Part B, 2014, 49(5): 374-380 (doi: 10.1080/03601234.2014.882179).

19. Raveau R., Fontaine J., Lounès-Hadj Sahraoui A. Essential oils as potential alternative biocontrol products against plant pathogens and weeds: a review. Foods, 2020, 9(3): 365 (doi: 10.3390/foods9030365).

20. Sarić-Krsmanović M., Umiljendić J.G., Radivojević L., Rajković M., Šantrić L., Đurović-Pejčev R. Chemical composition of Ambrosia trifida essential oil and phytotoxic effect on other plants. Chemistry \& Biodiversity, 2020, 17(1): e1900508 (doi: 10.1002/cbdv.201900508).

21. Mangao A., Arreola S., San Gabriel E., Salamanez K. Aqueous extract from leaves of Ludwigia hyssopifolia (G. Don) Exell as potential bioherbicide. Journal of the Science of Food and Agriculture, 2020, 100(3): 1185-1194 (doi: 10.1002/jsfa.10128).

22. Rahayuningsih S., Supriadi S. Herbicidal efficacy of acetic acid and citric acid base on broad leaf weeds of medicinal crops fields. Buletin Penelitian Tanaman Rempah dan Obat, 2016, 25(2): 137143 (doi: 10.21082/bullittro.v25n2.2014.137-143).

23. Lotina-Hennsen B., King-Díaz B., Pereda-Miranda R. Tricolorin a as a natural herbicide. Molecules, 2013, 18(1): 778-788 (doi: 10.3390/molecules18010778).

24. Chen S., Kang Y., Zhang M., Wang X., Strasser R.J., Zhou B., Qiang S. Differential sensitivity to the potential bioherbicide tenuazonic acid probed by the JIP-test based on fast chlorophyll fluorescence kinetics. Environmental and Experimental Botany, 2015, 112: 1-15 (doi: 10.1016/j.envexpbot.2014.11.009).

25. Спиридонов Ю.Я., Жемчужин С.Г., Клейменова И.Ю., Босак Г.С. Современное состояние проблемы изучения и применения гербицидов (дайджест публикаций за 2014-2017 гг.). Агрохимия, 2019, 6: 81-91 (doi: 10.1134/S0002188119060103). 
26. Graupner P.R., Gerwick B.C., Siddall T.L., Carr A.W., Clancy E., Gilbert J.R., Bailey K.L. Derby J.-A. Chlorosis inducing phytotoxic metabolites: new herbicides from Phoma macrostoma. In: ACS Symposium Series, Vol. 927. Natural products for pest management /A.M. Rimando, S.O. Duke (eds.). American Chemical Society, 2006: 37-47 (doi: 10.1021/bk-2006-0927.ch003).

27. Irvine N.M., Yerkes C.N., Graupner P.R., Roberts R.E., Hahn D.R., Pearce C., Gerwick B.C. Synthesis and characterization of synthetic analogs of cinnacidin, a novel phytotoxin from Nectria sp. Pest. Manag. Sci., 2008, 64(9): 891-899 (doi: 10.1002/ps.1579).

28. Hahn D.R., Graupner P.R., Chapin E., Gray J., Heim D., Gilbert J.R., Gerwick B.C. Albucidin: a novel bleaching herbicide from Streptomyces albus subsp. chlorinus NRRL B-24108. The Journal of Antibiotics, 2009, 62(4): 191-194 (doi: 10.1038/ja.2009.11).

29. Gerwick B.C., Brewster W.K., deBoer G.J., Fields S.C., Graupner P.R., Hahn D.R., Pearce C.J., Schmitzer P.R., Webster J.D. Mevalocidin: A novel, phloem mobile phytotoxin from Fusarium DA056446 and Rosellinia DA092917. J. Chem. Ecol., 2013, 39: 253-261 (doi: 10.1007/s10886013-0238-7).

30. Quy T.N., Xuan T.D., Andriana Y., Tran H., Khanh T.D., Teschke R. Cordycepin isolated from Cordyceps militaris: its newly discovered herbicidal property and potential plant-based novel alternative to glyphosate. Molecules, 2019, 24(16): 2901 (doi: 10.3390/molecules24162901).

31. Choi J.-S., Park N.-J., Lim H.-K., Ko Y.-K., Kim Y.-S., Ryu S.-Y., Hwang I.-T. Plumbagin as a new natural herbicide candidate for Sicyon angulatus control agent with the target 8-amino-7oxononanoate synthase. Pesticide Biochemistry and Physiology, 2012, 103(3): 166-172 (doi: 10.1016/j.pestbp.2012.04.007).

32. Demasi S., Caser M., Vanara F., Fogliatto S., Vidotto F., Negre M., Trotta F., Scariot V. Ailanthone from Ailanthus altissima (Mill.) Swingle as potential natural herbicide. Scientia Horticulturae, 2019, 257: 108702 (doi: 10.1016/j.scienta.2019.108702).

33. Yan Y., Liu Q., Zang X., Yuan S., Bat-Erdene U., Nguyen C., Gan J., Zhou J., Jacobsen S.E., Tang Y. Resistance-gene-directed discovery of a natural-product herbicide with a new mode of action. Nature, 2018, 559: 415-418 (doi: 10.1038/s41586-018-0319-4).

34. Maienfisch P., Mangelinckx S. Recent innovation in crop protection research. In: Recent highlights in the discovery and optimization of crop protection products /P. Maienfisch, S. Mangelinckx (eds.). Elsevier Inc, 2021: 1-23 (doi: 10.1016/B978-0-12-821035-2.00001-2).

35. Rimando A.M., Duke S.O. Natural products for pest management. In: ACS Symposium Series, Vol. 927. Natural products for pest management /A.M. Rimando, S.O. Duke (eds.). American Chemical Society, 2006: 2-21 (doi: 10.1021/bk-2006-0927.ch001).

36. Верещагин А.Л., Захарьева Ю.И. Повышение эффективности n-(фосфонометил)-глицина при совместном применении с органическими кислотами - интермедиатами цикла Кребса. Экологический вестник Северного Кавказа, 2014, 10(1): 47-50.

37. Travlos I., Rapti E., Gazoulis I., Kanatas P., Tataridas A., Kakabouki I., Papastylianou P. The herbicidal potential of different pelargonic acid products and essential oils against several important weed species. Agronomy, 2020, 10(11): 1687 (doi: 10.3390/agronomy10111687).

38. Берестецкий А.О., Полуэктова Е.В., Мищенко А.В., Первушин А.Л., Сабашук Ю.А., Далинова А.А., Дубовик В.Р. Оптимизация получения и применения фитотоксинов грибов для борьбы с сорными растениями. Мат. ІІІ Межд. науч. конф. «Современное состояние, проблемы и перспективы развития аграрной наук». Ялта, 2018: 104-106.

39. Duke S., Owens D., Dayan F. The growing need for biochemical bioherbicides. In: ACS Symposium Series, Vol. 1172. Biopesticides: state of the art and future opportunities /A.D. Gross, J.R. Coats, S.O. Duke, J.N. Seiber (eds.). American Chemical Society, 2014: 31-43 (doi: 10.1021/bk-2014-1172.ch003).

40. Перечни опасных и особо опасных для растений и продукции растительного происхождения вредных организмов. Мат. ІІІ Всероссийского съезда по защите растений «Фитосанитарная оптимизация агроэкосистем». СПб, 2013, 1: 459-463.

41. Приказ Министерства сельского хозяйства Российской Федерации от 26 декабря 2007 г. N 673 «Об утверждении перечня карантинных объектов» (Зарегистрировано в Минюсте РФ 17 января 2008 г. N 10903).

42. Федеральная служба государственной статистики. Сельское хозяйство, охота и лесное хозяйство. Режим доступа: https://www.gks.ru/enterprise_economy?print=1. Дата обращения: 01.06.2021.

43. Протасова Л.Д., Ларина Г.Е. Конкурентоспособность сорных растений в агроценозе. Агрохимия, 2009, 6: 67-85.

44. Шпанев А.М. Подходы к оценке вредоносности сорных растений в агроценозах. Вестник защиты растений, 2011, 4: 57-70.

45. Шпанев А.М. Фитосанитарные аспекты возделывания сои в центральном Черноземье. Защита и карантин растений, 2012, 3: 40-42.

46. Шпанев А.М. Фитосанитарное состояние посевов гречихи и потери урожая от вредных организмов на юго-востоке Центрально-Черноземной зоны. Сельскохозяйственная биология, 2013, 5(48): 106-112. 
47. Голубев А.С., Маханькова Т.А., Свирина Н.В. Новый гербицид Килео на основе глифосата и 2,4-Д. Известия Санкт-Петербургского государственного аграрного университета, 2017, 1 (46): $80-84$.

48. Голубев А.С., Маханькова Т.А. Перспективы борьбы с сорняками без глифосата. Новые и нетрадиционные растения и перспективы их использования, 2018, 13: 504-506.

49. Маханькова Т.А., Голубев А.С. Гербициды для зерновых колосовых культур. Защита и карантин растений, 2021, 1: 49-84.

50. Маханькова Т.А., Голубев А.С. Гербициды для кукурузы. Защита и карантин растений, 2018, 2: 37-64.

51. Маханькова Т.А., Голубев А.С. Гербициды для подсолнечника. Защита и карантин растений, 2019, 2: 37-63.

52. Редюк С.И. Защита картофеля от сорных растений. Вестник защиты растений, 2017, 2(92): 55-58.

53. Guske S., Schulz B., Boyle C. Biocontrol options for Cirsium arvense with indigenous fungal pathogens. Weed Research, 2004, 44(2): 107-116 (doi: 10.1111/j.1365-3180.2003.00378.x).

54. Müller E, Nentwig W. Plant pathogens as biocontrol agents of Cirsium arvense - an overestimated approach? NeoBiota, 2011, 11: 1-24 (doi: 10.3897/neobiota.11.1803).

55. Bailey K., Derby J.A., Bourdôt, G., Skipp B., Cripps M., Hurrell G., Saville D., Noble A. Plectosphaerella cucumerina as a bioherbicide for Cirsium arvense: proof of concept. BioControl, 2017, 62: 693-704 (doi: 10.1007/s10526-017-9819-7).

56. Национальный доклад о карантинном фитосанитарном состоянии территории Российской Федерации в 2018 году. Защита и карантин растений, 2019, 7: 6-14.

57. Силаев А.И., Поляков С.С. Эффективность применения гербицидов Горчак и Горгон для борьбы с Acroptilon repens в нижнем Поволжье. Аграрный научный журнал, 2017, 4: 49-52.

58. Силаев А.И., Поляков С.С., Маханькова Т.А. Фитотоксичность гербицидов, применяемых для борьбы с горчаком ползучим. Фермер. Поволжье, 2019, 6 (83): 70-74.

59. Ou X., Watson A.K. Mass culture of Subanguina picridis and its bioherbicidal efficacy on Acroptilon repens. Journal of Nematology, 1993, 25(1): 89-94.

60. Ramezani S., Saharkhiz M.J., Ramezani F., Fotokian M.H. Use of essential oils as bioherbicides. Journal of Essential Oil Bearing Plants, 2008, 11(3): 319-327 (doi: 10.1080/0972060X.2008.10643636).

61. Трофименко С.Л., Ракова К.А. Заболеваемость поллинозом в Ростове-на-Дону. Российская ринология, 2015, 1: 36-39 (doi: 10.17116/rosrino201523136-39).

62. Маханькова Т.А., Долженко В.И. Современный ассортимент гербицидов для защиты зерновых культур. Защита и карантин растений, 2013, 10: 46-50.

63. Кузнецова С.В., Багринцева В.Н. Гербициды для борьбы с амброзией в посевах кукурузы. Защита и карантин растений, 2019, 6: 41-43.

64. Golubev A.S. Study of the efficiency of a new herbicide benito on soybeans. Plant Protection News, 2019, 4(102): 54-59 (doi: 10.31993/2308-6459-2019-4-102-54-59).

65. Лучинский С.И., Маковеев А.В. Гербицид Евро-Лайтнинг в посевах подсолнечника. Политематический сетевой электронный научный журнал Кубанского государственного аграрного университета, 2011, 69: 401-412.

66. Есипенко Л.П., Савва А.П., Тележенко Т.Н., Замотайлов А.С., Хомицкий Е.Е. Методы борьбы с амброзией полыннолистной в России. Мат. Межд. науч.-практ. конф. «Биологическая защита растений - основа стабилизации агроэкосистем». Краснодар, 2018: 387-392.

67. Dmitrović S., Perišić M., Stojić A. Živković S., Boljević J., Nestorović Živković J., Aničić N., Ristić M., Mišić D. Essential oils of two Nepeta species inhibit growth and induce oxidative stress in ragweed (Ambrosia artemisiifolia L.) shoots in vitro. Acta Physiologiae Plantarum, 2015, 37: 64 (doi: 10.1007/s11738-015-1810-2).

68. Lefebvre M., Leblanc M.L., Bourgeois G., Watson A.K. Intergenerational assessment of biofumigation on phenology of Ambrosia artemisiifolia and Abutilon theophrasti. Allelopathy Journal, 2019, 46(2): 163-184 (doi: 10.26651/allelo.j/2019-46-2-1206).

69. Лунева Н.Н. Сорные растения. Elytrigia repens (L.) Nevski - Пырей ползучий. В: Агроэкологический атлас России и сопредельных стран: экономически значимые растения, их вредители, болезни и сорные растения /Под ред. А.Н. Афонина, С.Л. Грин, Н.И. Дзюбенко, А.Н. Фролова (ред.). Режим доступа: http://www.agroatlas.ru/ru/content/weeds/Elytrigia_repens. Дата обращения: 01.06.2021.

70. Носкова Е.В. Влияние систем земледелия на показатели обилия сорных растений и урожайность кукурузы. Вестник АПК Верхневолжья, 2019, 2(46): 7-10 (doi: 10.35694/YARCX.2019.46.2.002).

71. Проворова О.Н., Панасин В.И., Григорович Л.М. Агрохимические аспекты эффективности применения гербицидов класса сульфонилмочевин при выращивании кукурузы (Zea mays L.) на зерно. Проблемы агрохимии и экологии, 2018, 1: 24-28.

72. Миренков Ю.А., Кажарский В.Р., Папсуев А.В., Булавин Л.А., Гвоздов А.П., Пынтиков С.А. О совершенствовании мер борьбы с многолетними сорными растениями. Вестник Белорусской государственной сельскохозяйственной академии, 2020, 1: 68-73. 
73. Ringselle B., De Cauwer B., Salonen J., Soukup J. A review of non-chemical management of couch grass (Elymus repens). Agronomy, 2020, 10(8): 1178 (doi: 10.3390/agronomy10081178).

74. Илларионов А.И. Современные методы и средства защиты озимой пшеницы от сорных растений. Вестник Воронежского государственного аграрного университета, 2019, 3(62): 7893 (doi: 10.17238/issn2071-2243.2019.3.78).

75. Попов Ю.В., Рукин В.Ф., Хрюкина Е.И. Своевременно реагировать на изменения фитосанитарного состояния картофеля. Защита и карантин растений, 2013, 11: 3-5.

76. Кондратьев А.А. Резистентность овсюга (Ayena fatua L.) к феноксапроп-п-этилу в условиях Приобья Алтая. Вестник Алтайского государственного аграрного университета, 2008, 1(39): 7-11.

77. Mortensen K., Hsiao A.I. Fungal infestation of seeds from seven populations of wild oats (Avena fatua L.) with different dormancy and viability characteristics. Weed Research, 1987, 27(4): 297 304 (doi: 10.1111/j.1365-3180.1987.tb00766.x).

78. de Luna L.Z., Kennedy A.C., Hansen J.C., Paulitz T.C., Gallagher R.S., Fuerst E.P. Mycobiota on wild oat (Avena fatua L.) seed and their caryopsis decay potential. Plant Health Progress, 2011, 12(1) (doi: 10.1094/PHP-2011-0210-01-RS).

79. Carsten L.D., Johnston M.R., Douglas L.I., Sands D.C. A field trial of crown rust (Puccinia coronata f. sp. avenae) as a biocontrol agent of wild oats on San Clemente Island. Biological Control, 2000, 19(2): 175-181 (doi: 10.1006/bcon.2000.0850).

80. Hetherington S.D., Auld B.A. Host range of Drechslera avenacea, a fungus with potential for use as a biological control agent of Avena fatua. Australasian Plant Pathology, 2001, 30(3): 205-210 (doi: 10.1071/ap01020).

81. Hetherington S.D., Smith H.E., Scanes M.G., Auld B.A. Effects of some environmental conditions on the effectiveness of Drechslera avenacea (Curtis ex Cooke) Shoem.: a potential bioherbicidal organism for Avena fatua L. Biological Control, 2002, 24(2): 103-109 (doi: 10.1016/s10499644(02)00020-8).

82. Kastanias M.A., Chrysayi-Tokousbalides M. Herbicidal potential of pyrenophorol isolated from a Drechslera avenae pathotype. Pest. Manag. Sci., 2000, 56(3): 227-232 (doi: 10.1002/(SICI)15264998(200003)56:3<227::AID-PS115>3.0.CO;2-A).

83. Kastanias M.A., Chrysayi-Tokousbalides M. Bioactivity of the fungal metabolite $(8 R, 16 R)-(-)-$ pyrenophorin on graminaceous plants. J. Agric. Food. Chem., 2005, 53(15): 5943-5947 (doi: 10.1021/jf050792m).

84. Aliferis, K.A., Chrysayi-Tokousbalides, M. Metabonomic strategy for the investigation of the mode of action of the phytotoxin $(5 \mathrm{~S}, 8 \mathrm{R}, 13 \mathrm{~S}, 16 \mathrm{R})-(-)$-pyrenophorol using $1 \mathrm{~h}$ nuclear magnetic resonance fingerprinting. J. Agric. Food. Chem., 2006, 54(5): 1687-1692 (doi: 10.1021/jf0527798).

85. Benchaa S., Hazzit M., Abdelkrim H. Allelopathic effect of Eucalyptus citriodora essential oil and its potential use as bioherbicide. Chem. Biodiversity, 2018, 15(8): e1800202 (doi: 10.1002/cbdv.201800202).

86. Benchaa S., Hazzit M., Zermane N., Abdelkrim H. Chemical composition and herbicidal activity of essential oils from two Labiatae species from Algeria, Journal of Essential Oil Research, 2019, 31(4): 335-346 (doi: 10.1080/10412905.2019.1567400).

87. Abdelgaleil S., Abdel-Razeek N., Soliman S. Herbicidal activity of three sesquiterpene lactones on wild oat (Avena fatua) and their possible mode of action. Weed Science, 2009, 57(1): 6-9 (doi: 10.1614/WS-08-093.1).

88. Anwar T., Qureshi H., Parveen N., Bashir R., Qaisar U., Munazir M., Yasmin S., Basit Z., Mahmood R., Nayyar B., Khani S., Khan S., Qureshi M., Wali M. Evaluation of bioherbicidal potential of Carica papaya leaves. Brazilian Journal of Biology, 2020, 80(3): 565-573 (doi: 10.1590/1519-6984.216359).

89. Голубев А.С., Борушко И.П., Долженко В.И. Эффективность глифосата и глюфосината аммония в борьбе с амброзией полыннолистной (Ambrosia artemisiifolia L.) в виноградниках. Садоводство и виноградарство, 2019, 4: 45-50 (doi: 10.31676/0235-2591-2019-4-45-50).

90. Чебановская А.Ф., Могилюк Н.Т. Возможность распространения горчака ползучего на территории Украины и меры борьбы с ним. Вестник АПК Ставрополья, 2014, 1(13): 42-45.

91. Zhang Y., Yang X., Zhu Y., Li L., Zhang Y., Li J., Song X., Qiang S. Biological control of Solidago canadensis using a bioherbicide isolate of Sclerotium rolfsii SC64 increased the biodiversity in invaded habitats. Biological Control, 2019, 139: 104093 (doi: 10.1016/j.biocontrol.2019.104093).

92. Camargo A., Stefanski F., Scapini T., Weirich S., Ulkovski C., Carezia C., Bordin E., Rossetto V., Júnior F., Galon L., Fongaro G., Mossi A., Treichel H. Resistant weeds were controlled by the combined use of herbicides and bioherbicides. Environmental Quality Management, 2019, 29: 37-42 (doi: 10.1002/tqem.21643).

93. Cai X., Gu M. Bioherbicides in organic horticulture. Horticulturae, 2016, 2(2): 3 (doi: 10.3390/horticulturae2020003).

94. Берестецкий А.О. Перспективы разработки биологических и биорациональных гербицидов. Вестник защиты растений, 2017, 1(91): 5-12. 
95. Полуэктова Е.В., Берестецкий А.О. Грибы рода Colletotrichum как продуценты биологически активных соединений и биогербицидов. Микология и фитопатология, 2018, 6(52): 367-381 (doi: 10.1134/S0026364818060053).

ФГБНУ Всероссийский НИИ защиты растений, 196608 Россия, г. Санкт-Петербург-Пушкин, ш. Подбельского, 3, e-mail: golubev100@mail.ru $\bowtie$, aberestetskiy@vizr.spb.ru

Поступила в редакцию 6 июля 2021 года

Sel'skokhozyaistvennaya biologiya [Agricultural Biology], 2021, V. 56, № 5, pp. 868-884

\title{
FUTURE DIRECTIONS FOR USE OF BIOLOGICAL AND BIORATIONAL HERBICIDES IN RUSSIA
} (review)

\author{
A.S. Golubev ${ }^{\bowtie}$, A.O. Berestetskiy
}

All-Russian Research Institute of Plant Protection, 3, sh. Podbel'skogo, St. Petersburg, 196608 Russia, e-mail golubev100@mail.ru ( $₫$ corresponding author), aberestetskiy@vizr.spb.ru

ORCID:

Golubev A.S. orcid.org/0000-0003-0303-7442

The authors declare no conflict of interests

Berestetskiy A.O. orcid.org/0000-0002-0612-6996

Received July 6, 2021

doi: 10.15389/agrobiology.2021.5.868eng

\section{Abstract}

The emergence of weed populations resistant to chemical herbicides leads to a widespread decrease in the effectiveness of the chemical control. This fact, along with the currently increasing consumer demand for organic food, leads to an awareness of the need to develop research on the development of biological means of protecting crops from weeds. Despite the fact that biological (BLH) and biorational herbicides (BRH) are being introduced in the market of weed control products in the United States, Canada, China and South Africa, no such products has been registered in the Russian Federation to date. At the same time, the development of research on the development of environmentally friendly means of weed control allows to count on a change in the existing situation in the foreseeable future (A.O. Berestetskiy, 2017; M. Triolet et al., 2020). The purpose of this literature review was to analyze the current range of chemical herbicides allowed for use in Russia in order to identify market niches that BLH and BRH may occupy in the near future. To assess the prospects of these products, first of all, the spectrum of their action was taken into account, due to the species specificity of plant pathogens, which is significantly narrower than the activity spectrum of chemical herbicides (A. Berestetsky et al., 2018; A. Berestetsky, 2021). The analysis was based on a list of pest organisms that are particularly dangerous for crops prepared by the All-Russian Research Institute for Plant Protection (2013), in which the following types of weeds were indicated: perennial sowthistle (Sonchus arvensis L.), Canada thistle (Cirsium setosum (Willd.) Bess.), field bindweed (Convolvulus arvensis L.), couch grass (Elytrigia repens (L.) Nevski), and wild oat (Avena fatua L.). The list was supplemented with two quarantine weeds, common ragweed (Ambrosia artemisiifolia L.) and Russian knapweed (Acroptilon repens DC.), which are limited in the territory of the Russian Federation, but are problematic for a number of regions. These types of weeds have different degrees of harmfulness in different crops (A.M. Shpanev, 2011). The analysis involved the most significant agricultural crops from the point of view of the structure of the arable land of the Russian Federation. The use of BLH and BRH seems most promising in orchards and vineyards, where, due to the exclusion of glyphosatebased herbicides, only gufosinate-ammonium is allowed for use (A.S. Golubev et al., 2018; 2019). In addition, BLH and BRH, used in combination with some herbicides, would increase the effectiveness of weed control and the duration of the protective effect. The risks of using BLH and BRH in orchards and vineyards do not look significant due to the relative isolation of these agroecosystems. Forage crops and greenhouse vegetables do not have much potential as niches for the use of BLH and BRH, forage crops due to low economic returns, and vegetables in greenhouses due to the peculiarities of their cultivation technology. The use of BLH and BRH in fields intended for sowing agricultural crops in the autumn period and in fallow fields looks promising. In the conditions of crop rotations, BLH and BRH can be applicable against perennial root-sprouting weeds and Russian knapweed during the growing season of soybeans, sunflower, and potatoes. For the last two crops, the use of BLH and BRH against common ragweed looks promising as well. It will be possible to occupy a niche associated with the destruction of grass weeds (such as couch grass or wild oat), in the conditions of the existing range of chemical herbicides, only for the suppression of resistant weed populations.

Keywords: bioherbicides, cereals, corn, soybean, sunflower, potato, orchard, Sonchus arvensis, Cirsium setosum, Convolvulus arvensis, Elytrigia repens, Avena fatua, Ambrosia artemisiifolia, Acroptilon repens. 